\title{
Technical Task and Quality Assurance Plan in Support of BNFL Part B: Studies of Ion Exchange Resin Integrity under Flowsheet Extremes: Part II
}

by

C. A. Nash

Westinghouse Savannah River Company

Savannah River Site

Aiken, South Carolina 29808

D. J. McCabe

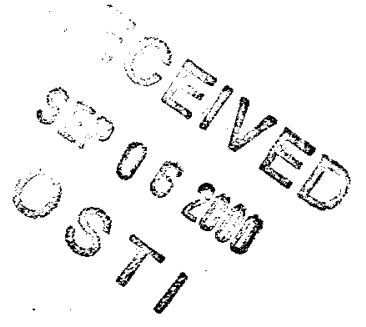

W. Crooks III

H. H. Saito

This paper was prepared in connection with work done under the above contract number with the U.S. Department of Energy. By acceptance of this paper, the publisher and/or recipient acknowledges the U. S. Government's right to retain a nonexclusive, royalty-free license in and to any copyright covering this paper, along with the right to reproduce and to authorize others to reproduce all or part of the copyrighted paper. 


\section{DISCLAIMER}

This report was prepared as an account of work sponsored by an agency of the United States. Government. Neither the United States Government nor any agency thereof, nor any of their employees, makes any warranty, express or implied, or assumes any legal liability or responsibility for the accuracy, completeness, or usefulness of any information, apparatus, product or process disclosed, or represents that its use would not infringe privately owned rights. Reference herein to any specific commercial product, process or service by trade name, trademark, manufacturer, or otherwise does not necessarily constitute or imply its endorsement, recommendation, or favoring by the United States Government or any agency thereof. The views and opinions of authors expressed herein do not necessarily state or reflect those of the United States Government or any agency thereof.

This report has been reproduced directly from the best available copy.

Available for sale to the public, in paper, from: U.S. Department of Commerce, National Technical Information Service, 5285 Port Royal Road, Springfield, VA 22161, phone: $(800) 553-6847$, fax: (703) 605-6900 email: orders@ntis.fedworld.gov online ordering: http://www.ntis.gov/ordering.htm

Available electronically at http://www.doe.gov/bridge Available for a processing fee to U.S. Department of Energy and its contractors, in paper, from: U.S. Department of Energy, Office of Scientific and Technical Information, P.O. Box 62, Oak Ridge, TN 37831-0062, phone: (865)576-8401, fax: (865)576-5728

email: reportsaadonis.osti.gov 


\section{DISCLAIMER}

Portions of this document may be illegible in electronic image products. Images are produced from the best available original document. 


\section{Task Technical and Quality Assurance Plan in Support of BNFL Part B}

\section{Studies of Ion Exchange Resin Integrity under Flowsheet Extremes: Part II}

Publication Date: April 17, 2000

W.J. Crooks III

C. A. Nash

D. J. McCabe

H. H. Saito

Authorized Derivative Classifier/RO

\section{DISCLAIMER NOTICE}

This report was prepared by Westinghouse Savannah River Company, Inc. (WSRC) on behalf of the U.S. Department of Energy (DOE), as an account of work sponsored by BNFL, Inc. Neither WSRC, DOE, the U.S. Government, or any person acting on their behalf makes any warranty, express or implied, or assumes any legal liability or responsibility for the accuracy, completeness, or usefulness of any information, apparatus, product, or process disclosed, or represents that its use would not infringe privately owned rights. Reference herein to any specific commercial product, process, or service by trade name, trademark, manufacturer, or otherwise, does not necessarily constitute or imply its endorsement, recommendation, or favoring by WSRC, DOE, or the U.S.

Government. The views and opinions of authors expressed herein do not necessarily state or reflect those of WSRC, DOE, or the U.S. Government. 


\begin{tabular}{|c|c|c|c|}
\hline $\begin{array}{l}\text { Task Leader } \\
\text { Sharles Lash }\end{array}$ & $\begin{array}{l}\text { Signature: } \\
\text { Charlea A. Nash }\end{array}$ & $\begin{array}{l}\text { Organization: } \\
\text { wyty }\end{array}$ & $\begin{array}{l}\text { Date: } \\
\text { s/olyeo }\end{array}$ \\
\hline Technical Reviewer (if required): & Signature: & Organization: & Date: \\
\hline Level 4 Manager: 5.T. Wach & Signature:jads & $\begin{array}{l}\text { Organization: } \\
W T T\end{array}$ & $\begin{array}{l}\text { Date: } \\
\text { 5/10/00 }\end{array}$ \\
\hline $\begin{array}{l}\text { Customer. - } \\
\text { MichAEL E. JoHinsors }\end{array}$ & Sipnature: & $\begin{array}{l}\text { Organization: } \\
\text { BNFL Ine. }\end{array}$ & $\begin{array}{l}\text { Date: } \\
\text { Y//8/2000 }\end{array}$ \\
\hline SRTC QAD (CQF): & Signature: 1 & $\begin{array}{l}\text { Organization: } \\
\text { SRTC QAD }\end{array}$ & $\begin{array}{l}\text { Date: } \\
\text { No MyYOO }\end{array}$ \\
\hline Other Approval (if required): & Srgnature: & Organization: & Date: \\
\hline Other Approval (if required): & Signature: & Organization: & Date: \\
\hline
\end{tabular}

\section{Distribution:}

W. L. Tamosaitis, 773-A

H. F. Sturm, 773-A

S. T. Wach, 773-A

C. T. Randall, 773-41A

J. J. Connelly, 773-42A

L. M. Nelson, 773-43A

T. K. Snyder, 704-T

BNFL File, c/o Belinda Beckum, 773-41 A, Room 260

\begin{tabular}{|l|l|l|l|}
\hline Revision & Page \\
Number: & Number: & Date: & Revision: \\
\hline
\end{tabular}




\section{INTRODUCTION}

\section{A. Task Definition}

This task will address four items related to ion exchange stability: (1) process upset evaluation of resin in contact with 1 molar sodium permanganate at 25 and $40^{\circ} \mathrm{C}$, (2) accelerated aging with nitric acid solution used during normal regeneration operations, (3) prolonged contacting of SuperLig ${ }^{\circledR} 644$ resin with 5 molar nitric acid at room temperature, and (4) prolonged contacting of SuperLig ${ }^{\oplus} 644$ resin with deionized water at $60 \pm 5^{\circ} \mathrm{C}$.

All work here is nonradioactive and does not use actual Hanford Tank samples.

\section{B. Customer/Requester}

This work was developed through SRTC recommendations forwarded to the BNFL Pretreatment Technical Manager and approved.

\section{Task Responsibilities}

The Special Projects group is responsible for directing the research. The Actinide Technology Section (ATS) group will perform the accelerated aging tests, the permanganate reaction tests, and the resin digestion/dissolution tests. Additional performance of the work is expected within the following groups:

The Analytical Development Section (ADS) is responsible for analyzing sample chemistry per quality assurance requirements as well as tracking samples within the LIMS system. ADS will analyze liquid samples by SVOA and gaseous samples by VOA Halocarbon ( $5 \mathrm{~mL}$ purge/trap) and VOA Halocarbon (direct gas loop). These VOA methods are consistent with EPA SW-846 methods.

The Materials Technology Section (MTS) will provide differential scanning calorimetry (DSC), thermal gravimetric analysis (TGA), and differential thermal analysis (DTA) (if applicable). These analyses will be controlled by the MTS Quality Assurance program and the instrument will be maintained as calibrated Measurement and Test Equipment.

\section{Task Deliverables}

One or more reports on the work covered by this TTP are to be delivered. The complete dataset will be available to the customer on request. Data and lab notebooks are handled-per the Part B1 contract with BNFL.

\section{TASK ACCEPTANCE CRITERIA}

Customer approvals of the TTP constitute acceptance of the work plan. 


\section{TASK ACTIVITIES}

\section{A. "Process upset" test of SuperLig ${ }^{\circledR} 644$ resin in contact with 1 molar sodium permanganate at 25 and $40{ }^{\circ} \mathrm{C}$.}

Resin is treated with a solution of 1 molar sodium permanganate in the RSST at room temperature. Significant self-heating is expected although no heat is applied. The reactivity of the system is characterized by monitoring the temperature and pressure changes. Only the gaseous products will be analyzed.

B. "Accelerated aging" test of SuperLig ${ }^{\circledR} 644$ resin with the nitric acid solution used during normal operation.

Resin in 0.5 molar nitric acid is heated in the Reactive System Screening Tool (RSST). The reactivity of the system is characterized by monitoring temperature and pressure changes. Solid, liquid and gaseous degradation products will be analyzed.

\section{Prolonged contacting of SuperLig ${ }^{\circledR} 644$ resin with 5 molar nitric acid solution at room temperature.}

Resin is contacted with 5 molar nitric acid at room temperature for at least 2 weeks or until it dissolves. Solid, liquid and gaseous degradation products will be analyzed.

D. Prolonged contacting of SuperLig ${ }^{\circledR} 644$ resin with deionized water at $60^{\circ} \mathrm{C}$. Resin is contacted with deionized water at $60^{\circ} \mathrm{C}$ for at least one week or until it dissolves. Solid, liquid and gaseous degradation products will be analyzed.

\section{A. "Process upset" test of SuperLig ${ }^{\circledR} 644$ resin in contact with 1 molar sodium permanganate at 25 and $40^{\circ} \mathrm{C}$}

Sodium permanganate is a powerful oxidizer that is expected to damage organic ion exchange resins. Work described in this section is intended to characterize the reaction that will occur as a result of the accidental addition of sodium permanganate solution to the SuperLig ${ }^{\circledR} 644$ ion exchange column.

1. Reactivity scoping test. This test will be performed in accord with the National Fire Protection Agency (NFPA) guidelines ${ }^{8}$ for working with potentially energetic compounds. SuperLig ${ }^{\circledR} 644$ resin $(<50 \mathrm{mg})$ will be placed on a watchglass. A drop of 1 molar sodium permanganate will be added, and the vigorousness of the reaction will be noted. As suggested by the NPFA guidelines, the mass of the reactivity scoping test will be performed in a chemical hood with less that $50 \mathrm{mg}$ of material, and personal protective equipment will include leather gloves and a face shield. In addition, a Plexiglas ${ }^{\mathrm{TM}}$ barrier will be in place between the test reaction and personnel.

2. Scale-up test in RSST at $25^{\circ} \mathrm{C}$. Based on the intensity of the reactivity scoping test, a mass scale-up test may be performed in the RSST. Since this test is simulating resin packed in a column, the target liquid:solid ratio of about $3: 1$. The RSST test cell will be loaded with a 
SuperLig ${ }^{\circledR} 644$ resin (2.5 grams). The test cell will be loaded into the RSST. Before the RSST test is started, the 1 molar sodium permanganate ( 7.9 grams) solution will be added externally to a sealed Parr bomb. A syringe will be used to force the permanganate solution through an extension tube into the test cell, and the Parr bomb will be monitored for temperature and pressure. This test will be repeated at least once.

3. Scale-up test in RSST at $40^{\circ} \mathrm{C}$. The RSST test cell will be loaded with SuperLig ${ }^{\circledR} 644$ resin ( 2.5 grams). The test cell will be loaded into the RSST. The 1 molar sodium permanganate solution will be warmed in a water bath before use. Before the RSST test is started, the warmed 1 molar sodium permanganate ( 7.9 grams) solution will be added externally to a sealed Parr bomb. A syringe will be used to force the permanganate solution through an extension tube into the test cell. This test will be repeated only if the results are significantly different from the Scale-up RSST test at $25^{\circ} \mathrm{C}$.

4. These SuperLig ${ }^{\circledR} 644$ resin/ $\mathrm{NaMnO}_{4}$ reactions are expected to self-heat and may evolve gas.

5. Analyze the RSST reaction profiles (time vs. temperature, self-heating rate vs. temperature, pressure rate vs. temperature, and pressure vs. temperature) to characterize the reactivity of the system.

6. Gaseous Products. At the conclusion of the RSST test, the test cell is allowed to return to room temperature prior to collection the off-gas sample. The off-gas is vented to a Tedlarim bag, and sealed. Submit the gas sample to ADS for prompt analysis by VOA Halocarbon (purge/trap scan) and VOA Halocarbon (direct gas loop).

7. Results will include RSST reaction profiles and VOA analyses of the gas.

\section{B. "Accelerated aging" test of SuperLig ${ }^{\circledR} 644$ with the nitric acid solution used during normal operation.}

The treatment to regenerate SuperLig ${ }^{\circledR} 644$ ion exchange resin involves loading and eluting a 0.5 molar nitric acid solution. A study of the resin-nitric acid mixture as a function of temperature will 1) simulate the accelerated aging of the resin-nitric acid mixture on the ion exchange column and 2) verify the safe operating conditions.

In an earlier RSST test of SuperLig ${ }^{\circledR} 644$ resin in 5 molar nitric acid solution, an exothermic reaction was observed in the range of 55 to $60^{\circ} \mathrm{C}$. The purpose of this test is to determine if a comparable exothermic reaction is observed for SuperLig ${ }^{\circledR} 644$ resin in 0.5 molar nitric acid solution.

1. SuperLig ${ }^{\circledR} 644$ resin (2.5 grams) and 0.5 molar nitric acid (7.9 grams) are loaded into the RSST, and containment is closed without backpressure. Since this test is simulating resin packed in a column, the target liquid:solid ratio of about 3:1 is much lower that our earlier RSST work (25:1 was used to simulate resin fines in the evaporator). All work should be performed in a chemical hood. 
2. Slowly heat the system at $15^{\circ} \mathrm{C} / \mathrm{hr}\left(0.25^{\circ} \mathrm{C} / \mathrm{min}\right)$ up to $90^{\circ} \mathrm{C}$, and hold 24 hours. However, if an exotherm is observed, the reaction will be stopped and the data will be analyzed.

3. Analyze the RSST reaction profiles (time vs. temperature, self-heating rate vs. temperature, pressure rate vs. temperature, and pressure vs. temperature) to characterize the reactivity of the system.

4. Solid Products. Determine if any solid is left in the sample. If so, separate the solids from the liquid by decanting and/or a fine-bore pipette tip. Any solid resin remaining after acid reaction is to be rinsed with 5:1 liquid:solid ratio of water, then dried on a watchglass in the chemical hood. Subsequent drying will be performed under high vacuum at $50^{\circ} \mathrm{C}$. All DSC analyses are to be performed with slow temperature rise $\left(5^{\circ} \mathrm{C} / \mathrm{min}\right)$ and with a purge of inert gas (nitrogen or argon). Heat to at least $300^{\circ} \mathrm{C}$, and if deemed useful, scan back down to ambient temperature.

5. Liquid Products. All liquid samples are analyzed for SVOA. In addition, a 3-mL aliquot of the liquid phase is to be evaporated to a solid paste on a watchglass in the chemical hood. Subsequent drying will be performed under vacuum at $50^{\circ} \mathrm{C}$ or less. The dried residue is to be tested by MTS for DSC. DTA and TGA may be performed if deemed necessary.

6. Gaseous Products. At the conclusion of the RSST test, the test cell is allowed to return to room temperature prior to collection the off-gas sample. The off-gas is vented to a TedlarTM bag, and sealed. Submit the gas sample to ADS for prompt analysis by VOA Halocarbon (purge/trap scan) and VOA Halocarbon (direct gas loop).

7. Results will include RSST reaction profiles, SVOA analyses of the liquids, and DSC/DTA/TGA scans of solids, and VOA analyses of the gas.

\section{Prolonged contacting of SuperLig ${ }^{\circledR} 644$ resin with 5 molar nitric acid solution at room temperature.}

One option to facilitate change-out of spent ion exchange resin is complete dissolution prior to transfer. An earlier RSST test indicated complete dissolution of SuperLig ${ }^{\circledR} 644$ in 5 molar nitric acid at $90^{\circ} \mathrm{C}$ in less than 24 hours, and indicated about $50 \%$ dissolution in water at $90^{\circ} \mathrm{C}$ for 24 hours . Furthermore, IBC stated that SuperLig ${ }^{\circledR} 644$ dissolved in 5 molar nitric acid (resin:acid $=1: 100$ ) at $25^{\circ} \mathrm{C}$ over a period of days. Work described in this section is intended to determine the time required to dissolve the resin in 5 molar nitric acid (resin:acid =1:25) at room temperature. If dissolution is not achieved in 2 weeks, the test may be terminated. If the case of a partial dissolution, solid, liquid and gaseous samples will still be analyzed as described below.

For each RSST test ( $0.4 \mathrm{~g}$ resin), a larger-scale beaker test ( $10 \mathrm{~g}$ resin) will be conducted simultaneously. The larger-scale beaker test will be used to visually monitor the dissolution of resin. The RSST will be run continuously and the Parr bomb will remain sealed until the resin 
has dissolved in the larger-scale beaker test. The target liquid:solid ratio of about 25:1 will be used for both RSST-scale and the larger-scale beaker tests.

1. RSST test. SuperLig ${ }^{\circledR} 644$ resin (0.4 grams) and 5 molar nitric acid (10.0 grams) are loaded into the RSST, and containment is closed without backpressure.

2. Slowly heat the system at $15^{\circ} \mathrm{C} / \mathrm{hr}\left(0.25^{\circ} \mathrm{C} / \mathrm{min}\right)$ up to $25^{\circ} \mathrm{C} \pm 5^{\circ} \mathrm{C}$, and hold for at least 2 weeks or until dissolution is complete. Visually monitor the larger-scale beaker test to determine when dissolution is complete.

3. Larger-scale beaker test. SuperLig ${ }^{\circledR} 644$ resin ( 4 grams) and 5 molar nitric acid (100 grams) are placed in a beaker, and stirred at a fast rate with a magnetic stir bar.

4. The beaker is covered with a watchglass and visually monitored for at least 2 weeks or until dissolution is complete. After the beaker-scale test indicates that dissolution is complete, the RSST test will be terminated, and the off-gas will be collected in a Tedlar ${ }^{\mathrm{TM}}$ bag.

5. Analyze the RSST reaction profiles (time vs. temperature, self-heating rate vs. temperature, pressure rate vs. temperature, and pressure vs. temperature) to characterize the reactivity of the system.

6. Solid Products. Determine if any solid is left in each sample. If so, separate the solids from the liquid by decanting and/or a fine-bore pipette tip. Any solid resin remaining after acid reaction are to be rinsed with 5:1 liquid:solid ratio of water, then dried on a watchglass in the chemical hood. Subsequent drying will be performed under high vacuum at $50^{\circ} \mathrm{C}$. All DSC analyses are to be performed with slow temperature rise $\left(5^{\circ} \mathrm{C} / \mathrm{min}\right)$ and with a purge of inert gas (nitrogen or argon). Heat to at least $300^{\circ} \mathrm{C}$, and if deemed useful, scan back down to ambient temperature.

7. Liquid Products. All liquid samples are analyzed for SVOA. In addition, a 3-mL aliquot of the liquid phase is to be evaporated to a solid paste on a watchglass in the chemical hood. Subsequent drying will be performed under vacuum at $50^{\circ} \mathrm{C}$ or less. The dried residue is to be tested by MTS for DSC. DTA and TGA may be performed if deemed necessary.

8. Gaseous Products. At the conclusion of the RSST test, the test cell is allowed to return to room temperature prior to collection the off-gas sample. The off-gas is vented to a TedlarTM bag, and sealed. Submit the gas sample to ADS for prompt analysis by VOA Halocarbon (purge/trap scan) and VOA Halocarbon (direct gas loop).

9. Results will include RSST reaction profiles, SVOA analyses of the liquids, and DSC/DTA/TGA scans of solids, and VOA analyses of the gas.

10. If the SuperLig ${ }^{\circledR} 644$ resin ( 4 grams) and 5 molar nitric acid (100 grams) completely dissolved in the large scale beaker test, that solution will be used in neutralization studies. If complete dissolution is not achieved, a solution will be prepared by heating a mixture of 
SuperLig ${ }^{\circledast} 644$ resin (4 grams) and 5 molar nitric acid (100 grams) to about $90^{\circ} \mathrm{C}$ until it completely dissolves.

a. 5-mL beaker test. A $5-\mathrm{mL}$ aliquot of "SuperLig ${ }^{\circledR} 644$ solution" will be place in a beaker, and 5 molar sodium hydroxide will be added to achieve $\mathrm{pH} 12-13$ (by $\mathrm{pH}$ paper). The neutralization reaction will be monitored for foaming. The tests will be repeated a minimum of three times.

b. RSST test. A 5-mL aliquot of "SuperLig ${ }^{\circledR} 644$ solution" will be loaded into the RSST. The amount of sodium hydroxide required to attain pH 12-13 in the 5-mL beaker test will be added externally to a sealed Parr bomb. A syringe will be used to force the sodium hydroxide through an extension tube into the test cell.

c. The reaction is expected to self-heat and may evolve gas. Analyze the RSST reaction profiles (time vs. temperature, self-heating rate vs. temperature, pressure rate vs. temperature, and pressure vs. temperature) to characterize the reactivity of the system.

\section{Prolonged contacting of SuperLig ${ }^{\circledR} 644$ resin with deionized water at $60^{\circ} \mathrm{C}$.}

Work is described in this section is intended to determine if the resin will completely dissolve in deionized water at $60{ }^{\circ} \mathrm{C}$.

1. RSST test. SuperLig ${ }^{\circledR} 644$ resin ( 0.4 grams) and deionized water ( 10.0 grams) are loaded into the RSST, and containment is closed without backpressure.

2. Slowly heat the system at $15^{\circ} \mathrm{C} / \mathrm{hr}\left(0.25^{\circ} \mathrm{C} / \mathrm{min}\right)$ up to $60^{\circ} \mathrm{C}$, and hold for at least one week or until dissolution is complete. Visually monitor the same-scale beaker test to determine when dissolution is complete.

3. Same-scale beaker test. SuperLig ${ }^{\circledR} 644$ resin ( 0.4 grams) and deionized water (10 grams) are placed in a beaker, and stirred at a fast rate with a magnetic stir bar.

4. The beaker is covered with a watchglass and visually monitored for at least one week or until dissolution is complete. After the beaker-scale test indicates that dissolution is complete, the RSST test will be terminated, and the off-gas will be collected in a Tedlar ${ }^{\mathrm{TM}}$ bag.

5. Analyze the RSST reaction profiles (time vs. temperature, self-heating rate vs. temperature, pressure rate vs. temperature, and pressure vs. temperature) to characterize the reactivity of the system.

6. Solid Products. Determine if any solid is left in each sample. If so, separate the solids from the liquid by decanting and/or a fine-bore pipette tip. Any solid resin remaining after reaction with de-ionized water is to be rinsed with 5:1 liquid:solid ratio of water, then dried on a watchglass in the chemical hood. Subsequent drying will be performed under high vacuum at $50^{\circ} \mathrm{C}$. All DSC analyses are to be performed with slow temperature rise $\left(5^{\circ} \mathrm{C} / \mathrm{min}\right)$ and with 
a purge of inert gas (nitrogen or argon). Heat to at least $300^{\circ} \mathrm{C}$, and if deemed useful, scan back down to ambient temperature.

7. Liquid Products. All liquid samples are analyzed for SVOA. In addition, a $3-\mathrm{mL}$ aliquot of the liquid phase is to be evaporated to a solid paste on a watchglass in the chemical hood. Subsequent drying will be performed under vacuum at $50^{\circ} \mathrm{C}$ or less. The dried residue is to be tested by MTS for DSC. DTA and TGA may be performed if deemed necessary.

8. Gaseous Products. At the conclusion of the RSST test, the test cell is allowed to return to room temperature prior to collection the off-gas sample. The off-gas is vented to a Tedlarm bag, and sealed. Submit the gas sample to ADS for prompt analysis by VOA Halocarbon (purge/trap scan) and VOA Halocarbon (direct gas loop).

9. Results will include RSST reaction profiles, SVOA analyses of the liquids, and DSC/DTA/TGA scans of solids, and VOA analyses of the gas.

\section{E. Control of Experimental Conditions}

These non-radioactive tests will use reagent grade chemicals weighed on calibrated balances. Weights will fall within $\pm 5 \%$ of the desired value.

The experiments will occur at constant temperature. Personnel will measure the temperatures to $\pm 2{ }^{\circ} \mathrm{C}$ using thermometers and/or thermocouples that are traceable to NIST standards.

\section{F. Blanks and Controls}

The WPTS personnel will submit blanks and control samples to ADS or to MTS to monitor preparations and analytical methods. Control samples will contain a defined quantity of the analyte of interest.

\section{G. Measuring and Testing Equipment (M\&TE)}

This task will use the following M\&TE: Balances, thermometers, pressure gauges thermocouples, and differential scanning calorimeters (DSC, DTA, and TGA are all done with the same instrument).

The thermometers, thermocouples, and pressure gauges will receive calibration against NISTtraceable standards by the SRTC Standards Laboratory. Balance calibration will use reference weights traceable to NIST standards. The DSC will use a standard reference material (typically silver metal) for calibration.

\section{H. Documentation}

A numbered notebook will record all pertinent instructions, results, and calculations in accordance with Manual L1, SRTC Procedures Manual, procedure 4.19. ${ }^{8}$ A laboratory notebook 
will provide lifetime storage as a record. Drafts of all preliminary reports will receive review by selected WPTS for comments. Final reports will issue after comment resolution.

IV. TASK SCHEDULE Activities are performed in accordance with the BNFL Part B1 Schedule.

The following schedule estimates the completion of the deliverable for this task.
Issue Task Plan
April 17, 2000
Complete Experiments
June 5,2000
Issue Report
June 15,2000

V. RESEARCH FACILITY PLANNING - Laboratory space is available for this task.

VI. PROGRAMMATIC RISK REVIEW. Table 1 depicts the programmatic risks associated with this task and the associated mitigation, where identified.

Table 1. Programmatic Risk and Mitigation

\begin{tabular}{|c|c|c|}
\hline Risk Factor & Event & Mitigation \\
\hline Equipment & Failure & Replacement of item \\
\hline Analytical Support & Failure & $\begin{array}{l}\text { ADS has backup } \\
\text { instruments }\end{array}$ \\
\hline Personnel & $\begin{array}{l}\text { Ilness } \\
\text { Vacation }\end{array}$ & $\begin{array}{l}\text { Primary and secondary researchers } \\
\text { and analysts identified. }\end{array}$ \\
\hline Facility & $\begin{array}{l}\text { Outage } \\
\text { Electrical } \\
\text { Ventilation }\end{array}$ & Adjust testing intervals. \\
\hline
\end{tabular}

\section{R\&D HAZARDS SCREENING CHECKLIST}

Listed below are characteristics of an experiment/project that may present hazards above normal risks to SRTC. Circle YES or NO for each item listed. For each "yes" answer you will be directed to a secondary hazard review or reviews that will direct completion of specific actions need to manage/mitigate the identified hazard.

Energies

A. Electricity (exposed energized parts $>50 \mathrm{~V}$ ). $\quad$ YES See Figures 4 \& 11 . 
B. Fissionable materials.

Specify:

See Figures 4, 5, 6, 7, 9, \& 11 .

C. High noise levels ( $>85 \mathrm{dBA})$.

YES

No

See Figures 4, 8, \& 11.

D. Microwave/radiofrequencies ( $30 \mathrm{KHz}-300 \mathrm{GHz}$ ), electric or magnetic fields.

See Figures 4, 8, \& 11.

YES

NO

E. Lasers (other than class 1).

YES

NO

See Figures $4,8, \& 11$

F. Moving equipment (exposed belts, chains, gears, pinch rollers, pulleys, rotating shafts/blades, wheels, etc.)

YES

$\underline{\text { NO }}$

See Figures 4 \& 11 .

G. Radioactive materials.

YES

NO

Specify: Radionuclides

Amount:

Physical Form:

See Figures 4, 5, 6, 7, 9, \& 11 .

H. Static magnetic fields $>600$ Gauss.

YES

NO

See Figures 4, 8, \& 11 .

I. Sub-radiofrequency $(<30 \mathrm{KHz})$ electric and magnetic fields.

YES

NO

See Figures 4, 8, \& 11 .

J. Temperatures $(<32 \bullet \mathrm{F}$ or $>150 \cdot \mathrm{F})$. Consider furnaces, ovens, dryers, boilers, steam systems, heaters, dewars, chillers, and release of compressed gases.

See Figures $4,8,10, \& 11$.

K. Vacuum (external pressure $>15 \mathrm{PSI}$ ).

$\underline{\text { YES }}$

NO

See Figures 4, 8, \& 11.

L. Pressure (compressible materials $>30 \mathrm{PSI}$; or non-compressible materials > 150PSI).

YES

NO

See Figures 4, 8, \& 11.

M Pressure vessels (> 15PSI and >6"ID; and/or

contain toxic, corrosive, or nuclear materials).

YES

NO

See Figures 4,8 \& 11 .

\section{Work Site Environmental Conditions}

A. Boating or work over water.

YES

NO

See Figure 4, 8, \& 11.

B. Cold or heat stress conditions.

YES

NO 
C. Confined spaces/trenches/or evacuations.

YES

NO

See Figures 4, 8, \& 11 .

D. Flammable atmospheres ( $>10 \%$ LEL).

YES

NO

See Figures 4, 8, 10, \& 11 .

E. Oxygen deficient atmospheres $(<19.5 \%$ O2).

YES

NO

See Figures $4,8, \& 11$.

F. Toxic atmosphere (airborne contaminant concentrations expected to exceed $50 \%$ of the Threshold Limit Value).

YES

NO

See Figures 4, 5,-8, \& 11 .

G. Activity performed in a nuclear facility.

$\underline{\text { YES }}$

NO

See Figure 6.

H. Work with radioactive or contaminated material or entry into controlled area.

YES

NO

See Figures $6 \& 7$.

\section{Hazardous Materials}

A. Biological Agents.

YES

$\underline{\text { NO }}$

See Figures 4, 5, 8, 9, \& 11 .

B. Carcinogens, mutagens, teratogens.

YES

NO

Specify:

See Figures 4, 5, 8, 9, \& 11 .

C. Corrosives.

YES

NO

See Figures 4, 5, 8, 9, \& 11 .

YES

$\underline{\text { NO }}$

D. Cryogenic gases/liquids.

See Figures 4, 8, \& 11.

YES

NO

E. Flammable/com

See Figures $4,5,8,9,10, \& 11$.

F. Toxic Chemicals.

YES

NO

Specify: Amount:

See Figures 4, 5, 8, 9, \& 11.

G. Oxidizers.

$\underline{\text { YES }}$

NO

Specify: Amount: $<100 \mathrm{~g}$

See Figures 4, 5, 8, 9, 10, \& 11 .

H. Hydrocarbons ( $>55$ gallons).

YES

$\underline{\text { NO }}$

See Figures 4, 5, 8, 9, \& 11.

I. Any hazardous substance.

YES

NO 
BNF-003-98-0225, rev. 0 Final In Support of BNFL Part B

Page 13 of $2 \times 18$

\section{Environmental Compliance}

A. Release of regulated gas or particulate to the environment. See Figure 9.

B. Release of regulated materials to a waste disposal system. See Figure 9.

YES

NO

C. Waste disposal problems (including equipment).

YES

NO

See Figure 9.

D. Creation of radioactive waste.

YES

NO 


\section{REFERENCES}

1. TWRS Privatization, Contract No. DE-RP06-96RL13308, Modification No. A005.

2. M. E. Johnson, "Investigation of entrained solids filtration and Sr/TRU Precipitation", BNFL ref. Number 2003, March 11, 1999.

3. M. E. Johnson, "Request to Conduct Analysis of Archive AN-107 Sample and Permanganate Precipitation Trial", BNFL ref. Number 2140, March 23, 1999.

4. P. S. Townson, "TWRS-P Contract No. DE-AC06-96RL13308-W375, Sr/TRU Precipitation and Ultrafiltration Test Specification, BNFL ref. Number 1389, Jan. 22, 1999.

5. M. E. Johnson, "TWRS-P Contract No. DE-AC06-96RL13308-W375, BNFL ref. Number 000453

6. "Technical Notebook Use," Manual L1, Procedure 4.19, Rev. 5, February 2, 1998

7. "Conduct of Research and Development," WSRC-IM-97-0024, Rev. 0, May 31, 1998.

8. U.S. Department of Energy, "DOE Explosives Safety Manual," DOE M 440.1-1, September 30, 1995.

9. M. E. Johnson, "Evaluating Affects from Contacting SuperLig 644 Resin with Permanganate and Nitric Acid", BNFL ref. Number 012612, April 5, 2000. 


\section{Attachment 1. QA Plan Checklist}

Listed below are the sections of the WSRC Quality Assurance Manual 1Q. The contents of the 1Q Manual are responsive to the requirements of DOE Quality Assurance Orders, 10CFR830.120 and to the WSRC Quality Assurance Management Plan (WSRC-RP-92-225). WSRC IQ sections applicable to the work being performed for the TWRS Privatization Project should be indicated (mark Yes or No). Also indicate procedures SRTC implements to control the work (including L1, 8.21, Supplemental QA Requirements for RW-0333P, if applicable).

\begin{tabular}{|c|c|c|}
\hline Yes & No & Title \\
\hline 16) & 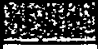 & 1.1 ORGANIZATION \\
\hline $\mathbf{X}$ & & 1Q, QAP 1-1, Organization \\
\hline $\mathbf{x}$ & & $\mathrm{Ll}, 1.02$, SRTC Organization \\
\hline 36 & 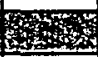 & 1-2 STOP WORK \\
\hline $\mathbf{X}$ & & 1Q, QAP 1-2, Stop Work \\
\hline 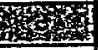 & 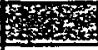 & 2-1 QUALITY ASSURANCE PROGRAM \\
\hline $\mathbf{X}$ & & 1Q, QAP 2-1, Quality Assurance Program \\
\hline $\mathbf{X}$ & & L1, 8.01, SRTC QA Program Implementation \\
\hline $\mathbf{X}$ & & L1, 8.02, SRTC QA Program Clarifications, Attachment 8.2-1 \\
\hline 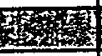 & 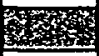 & 2-2 PERSONNEL TRAINING \& QUALIFICATION \\
\hline $\mathbf{X}$ & & 1Q, QAP 2-2, Personnel Training \& Qualification \\
\hline $\mathbf{X}$ & & L1, 5.01, SRTC Training, Orientation \& Employee Development \\
\hline & $\mathbf{X}$ & L1, 1.32, Read \& Sign \\
\hline $\mathbf{X}$ & & L1, 1.33, Employee \& Facility Access Orientation \\
\hline 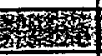 & 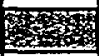 & 2-3 CONTROL OF RESEARCH \& DEVELOPMENT ACTIVITIES \\
\hline $\mathbf{X}$ & & 1Q, QAP 2-3, Control of Research \& Development Activities \\
\hline $\mathbf{X}$ & & L1, 8.02, SRTC QA Program Clarifications, Attachment 8.2-3 \\
\hline$\underline{\mathbf{X}}$ & & L1, 7.10, Control of Technical Work \\
\hline $\mathbf{X}$ & & $\mathrm{Ll}, 4.19$, Laboratory Notebook Use \\
\hline $\mathbf{X}$ & & L13-1, GT-QA-2-6, Analytical Support of Tasks \\
\hline $\mathbf{X}$ & & E7, 2.31, Engineering Calculations \\
\hline 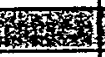 & (1) & 2-4 AUDITOR/LEAD AUDITOR QUALIFICATION \& CERTIFICATION \\
\hline & $\mathbf{X}$ & 1Q, QAP 2-4, Auditor/Lead Auditor Qualification \& Certification \\
\hline (3) & Sty & $\begin{array}{l}\text { 2-5 QUALIFICATION \& CERTIFICATION OF INDEPENDENT } \\
\text { INSPECTION PERSONNEL }\end{array}$ \\
\hline & $\mathbf{X}$ & 1Q, QAP 2-5, Qualification \& Certification of Independent Inspection Personnel \\
\hline 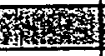 & 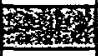 & 2-6 QA MANUAL REVISION \\
\hline & $\mathrm{X}$ & 1Q, QAP 2-6, QA Manual Revisions \\
\hline 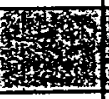 & Why & $\begin{array}{l}2-7 \text { QA PROGRAM REQUIREMENTS FOR ANALYTICAL } \\
\text { MEASUREMENT SYSTEMS }\end{array}$ \\
\hline & $\mathbf{X}$ & 1Q, QAP 2-7, QA Program Requirements for Analytical Measurement Systems \\
\hline 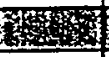 & 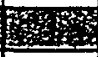 & 2-10 INDEPENDENT INSPECTION PERSONNEL ON-THE-JOB TRAINING \\
\hline & $\mathbf{X}$ & 1Q, QAP 2-10, Independent Inspection Personnel - OTJ Training \\
\hline 31 & 1. & 3.1 DESIGN CONTROL \\
\hline
\end{tabular}


BNF-003-98-0225, rev. 0 Final

In Support of BNFL Part B

Page 16 of 2118

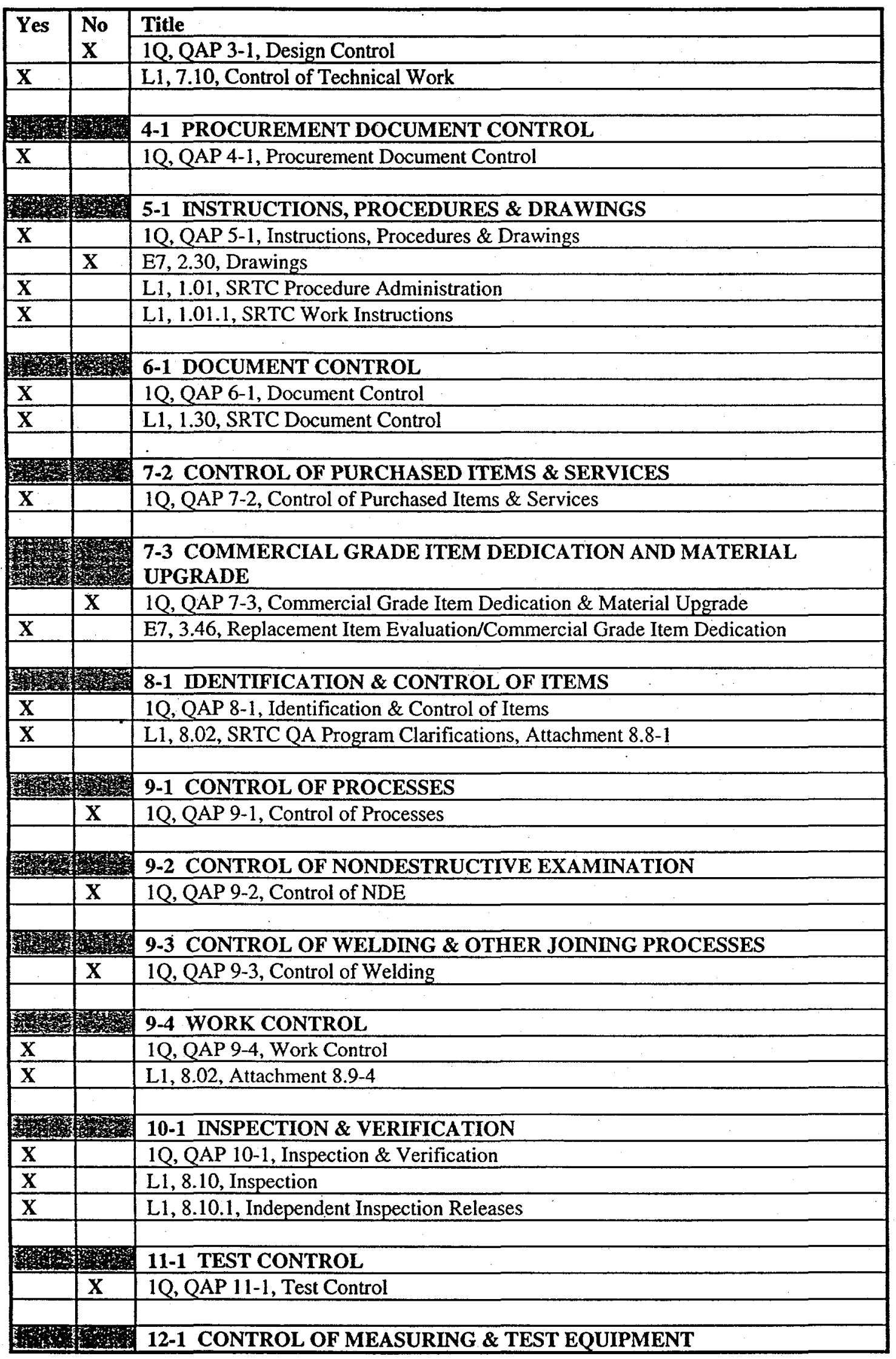




\begin{tabular}{|c|c|c|}
\hline \multirow{2}{*}{$\begin{array}{l}\text { Yes } \\
\mathrm{X}\end{array}$} & \multirow{2}{*}{ No } & \multirow{2}{*}{$\begin{array}{l}\text { Title } \\
\text { 1Q, QAP 12-1, Control of Measuring \& Test Equipment }\end{array}$} \\
\hline & & \\
\hline $1 \%$ & ox & 12, CONTROI OF INCTAI I ED PDOCFCS INCTPUMENTATION \\
\hline $\mathbf{X}$ & & 10. OAP 12-2, Control of Installed Process Instrumentation \\
\hline 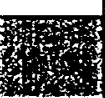 & 4 & $\begin{array}{l}\text { 12-3 CONTROL \& CALIBRATION OF RADIATION MONITORING } \\
\text { EQUIPMENT }\end{array}$ \\
\hline & $\mathbf{X}$ & 1Q, QAP 12-3, Control of Radiation Monitoring Equipment \\
\hline 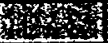 & (3) & 13-1 PACKAGING, HANDLING, SHIPPING \& STORAGE \\
\hline $\mathbf{X}$ & & 1Q, QAP 13-1, Packaging, Handling, Shipping \& Storage \\
\hline $\mathbf{X}$ & & L1, 8.02, SRTC QA Program Clarifications, Attachment 8.13-1 \\
\hline 36. & 36 & 14-1 INSPECTION, TEST \& OPERATING STATUS \\
\hline & $\mathbf{X}$ & 1Q, QAP 14-1, Inspection, Test \& Operating Status \\
\hline $\mathbf{X}$ & & L1, 8.02, SRTC QA Program Clarifications, Attachment 8.14-1 \\
\hline 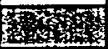 & 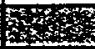 & 15-1 CONTROL OF NONCONFORMING ITEMS \\
\hline $\mathrm{X}$ & & 1Q, QAP $15-1$, Control of Nonconforming Items \\
\hline$\underline{\mathbf{X}}$ & & L1, 8.02, SRTC QA Program Clarifications, Attachment 8.15-1 \\
\hline 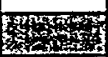 & ST & 15-2 CONTROL OF NONCONFORMING ACTIVITIES \\
\hline $\mathbf{X}$ & & 1Q, QAP 15-2, Control of Nonconforming Activities \\
\hline $\mathbf{X}$ & & L1, 8.02, SRTC QA Program Clarifications, Attachment 8.15-2 \\
\hline 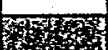 & Whim & 16-1 CORRECTIVE ACTION SYSTEM \\
\hline $\mathbf{X}$ & & 1Q, QAP 16-1, Corrective Action System \\
\hline & & \\
\hline 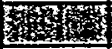 & 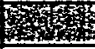 & 16-2 QUALITY ALERT \\
\hline $\mathbf{X}$ & & 1Q, QAP $16-2$, Quality Alert \\
\hline & & \\
\hline (1) & S- & 17-1 QA RECORDS MANAGEMENT \\
\hline $\mathbf{X}$ & & 1Q, QAP 17-1, QA Records Management \\
\hline $\mathbf{X}$ & & L1, 8.02, SRTC QA Program Clarifications, Attachment 8.17-1 \\
\hline & & \\
\hline 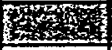 & 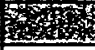 & 18-2 QUALITY ASSURANCE SURVEILLANCES \\
\hline $\mathbf{X}$ & & 1Q, QAP 18-2, Quality Assurance Surveillance \\
\hline $\mathbf{X}$ & & $\mathrm{L} 1,8.18 .1$, Surveillance \\
\hline 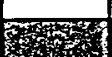 & 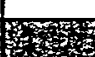 & 18-3 QUALITY ASSURANCE EXTERNAL AUDITS \\
\hline $\mathbf{X}$ & & 1Q, QAP 18-3, Quality Assurance External Audits \\
\hline $\mathbf{X}$ & & L1, 8.18, SRTC Quality Assurance Audit Program \\
\hline 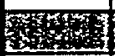 & 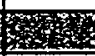 & 18-4 MANAGEMENT ASSESSMENTS \\
\hline $\mathbf{X}$ & & 1Q, QAP 18-4, Management Assessments \\
\hline (m) & 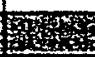 & 18-6 QUALITY ASSURANCE INTERNAL AUDITS \\
\hline $\mathbf{X}$ & & 1Q, QAP 18-6, Quality Assurance Internal Audits \\
\hline 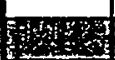 & He & 19-2 QUALITY IMPROVEMENT \\
\hline $\mathbf{x}$ & & 1Q, QAP 19-2, Quality Improvement \\
\hline
\end{tabular}




\begin{tabular}{|c|c|c|}
\hline Yes & No & Title \\
\hline \multirow[t]{2}{*}{$\mathbf{X}$} & & L1, 8.02, SRTC QA Program Clarifications, Attachment 8.19-2 \\
\hline & & 20-1 SOFTWARE QUALITY ASSURANCE \\
\hline$\underline{\mathbf{X}}$ & & 1Q, QAP 20-1, Software Quality Assurance \\
\hline \multirow[t]{2}{*}{$\underline{\mathbf{X}}$} & & L1, 8.20, Software Management \& Quality Assurance \\
\hline & He & 21-1 ENVIRONMENTAL QUALITY ASSURANCE \\
\hline & $\mathbf{X}$ & 1Q, QAP 21-1, QA Requirements for the Collection \& Evaluation of Environ. Data \\
\hline & 4 & $\begin{array}{l}\text { In addition to procedures noted above, if } \mathrm{RW}-0333 \mathrm{P} \text { requirements are invoked, } \\
\text { the following procedures may apply: }\end{array}$ \\
\hline & $\mathbf{X}$ & L1, 8.21, Supplemental QA Requirements for RW-0333P \\
\hline & $\mathbf{X}$ & L1, 3.07, Obtaining Analytical Services \\
\hline & $\mathbf{X}$ & L1, 2.21, Radioactive Sample Receiving, Labeling, \& Tracking \\
\hline & $\mathbf{X}$ & L1, 4.19, Laboratory Notebook Use \\
\hline
\end{tabular}

